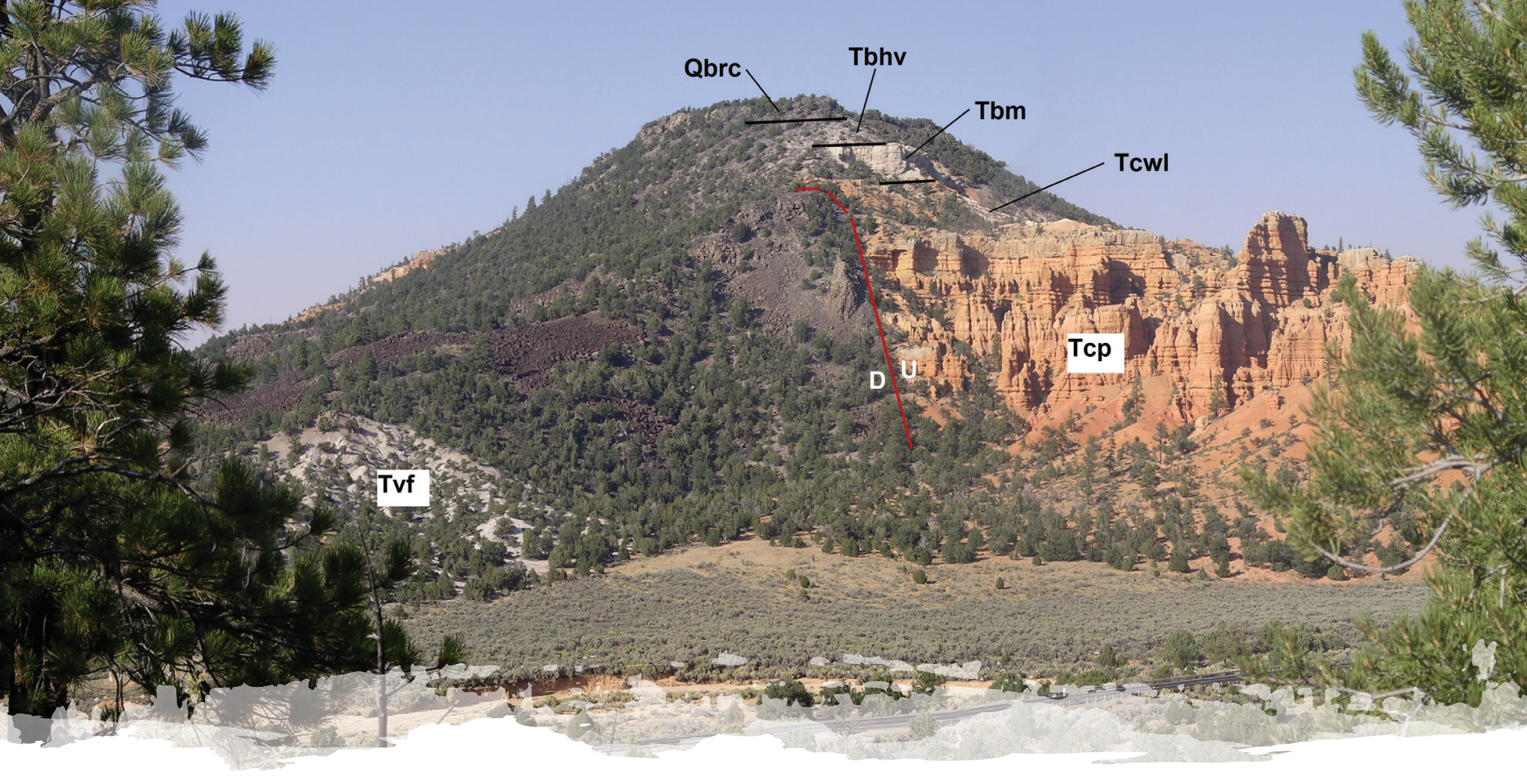

\title{
Sevier Fault at Red Canyon
}

Robert F. Biek

Utah Geological Survey, P.O. Box 146100, Salt Lake City, UT 84114-6100

bobbiek@utah.gov

\section{Utah Geosites \\ 2019}

Utah Geological Association Publication 48

M. Milligan, R.F. Biek, P. Inkenbrandt, and P. Nielsen, editors

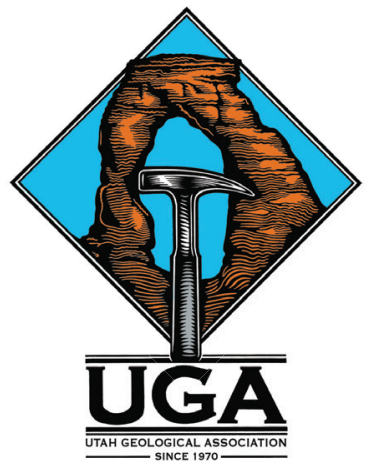




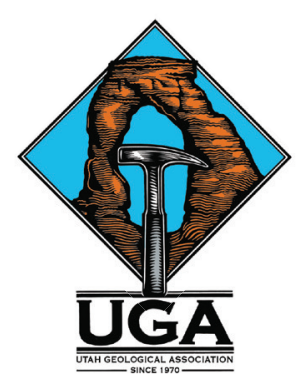

\section{Utah Geosites} 2019

\section{Utah Geological Association Publication 48}

M. Milligan, R.F. Biek, P. Inkenbrandt, and P. Nielsen, editors

Utah Geosites showcases some of Utah's spectacular geology, both little-known localities and sites seen by visitors to Utah's many national and state parks and monuments. The geosites reflect the interests of the many volunteers who wrote to share some of their favorite geologic sites. The list is eclectic and far from complete, and we hope that additional geosites will be added in the coming years. The Utah Geological Survey also maintains a list of geosites https://geology.utah.gov/apps/geosights/index.htm.

We thank the many authors for their geosite contributions, Utah Geological Association members who make annual UGA publications possible, and the American Association of Petroleum Geologists-Rocky Mountain Section Foundation for a generous grant for desktop publishing of these geosite papers.

Design and desktop publishing by Jenny Erickson, Graphic Designer, dutchiedesign.com, Salt Lake City, Utah.

This is an open-access article in which the Utah Geological Association permits unrestricted use, distribution, and reproduction of text and figures that are not noted as copyrighted, provided the original author and source are credited. See the Utah Geological Association website, www.utahgeology.org, and Creative Commons https://creativecommons.org/licenses/by/4.0/ for details.

Suggested citation for this geosite:

Biek, R.F., 2019, Sevier fault at Red Canyon, in Milligan, M., Biek, R.F., Inkenbrandt, P., and Nielsen, P., editors, Utah Geosites: Utah Geological Association Publication 48, 6 p., https://doi.org/10.31711/geosites.v1i1.53.

\section{Presidents Message}

I have had the pleasure of working with many different geologists from all around the world. As I have traveled around Utah for work and pleasure, many times I have observed vehicles parked alongside the road with many people climbing around an outcrop or walking up a trail in a canyon. Whether these people are from Utah or from another state or country, they all are quick to mention to me how wonderful our geology is here in Utah.

Utah is at the junction of several different geological provinces. We have the Basin and Range to the west and the Central Utah Hingeline and Thrust Belt down the middle. The Uinta Mountains have outcrops of some of the oldest sedimentary rock in Utah. Utah also has its share of young cinder cones and basaltic lava flows, and ancient laccoliths, stratovolcanoes, and plutonic rocks. The general public comes to Utah to experience our wonderful scenic geology throughout our state and national parks. Driving between our national and state parks is a breathtaking experience.

The "Utah Geosites" has been a great undertaking by many people. I wanted to involve as many people as we could in preparing this guidebook. We have had great response from authors that visit or work here in the state. Several authors have more than one site that they consider unique and want to share with the rest of us. I wanted to make the guidebook usable by geologists wanting to see outcrops and to the informed general public. The articles are well written and the editorial work on this guidebook has been top quality.

I would like to personally thank Mark Milligan, Bob Biek, and Paul Inkenbrandt for their editorial work on this guidebook. This guidebook could not have happened without their support. I would like to thank Jenny Erickson for doing the great desktop publishing and the many authors and reviewers that helped prepare the articles. Your work has been outstanding and will certainly showcase the many great places and geology of Utah. Last, but not least, Thank you to the American Association of Petroleum Geologists, Rocky Mountain Section Foundation for their financial support for this publication.

Guidebook 48 will hopefully be a dynamic document with the potential to add additional "geosites" in the future. I hope more authors will volunteer articles on their favorite sites. I would like to fill the map with locations so that a person or family looking at the map or articles will see a great location to read about and visit. Enjoy Guidebook 48 and enjoy the geology of Utah.

Peter J. Nielsen

2019 UGA President 


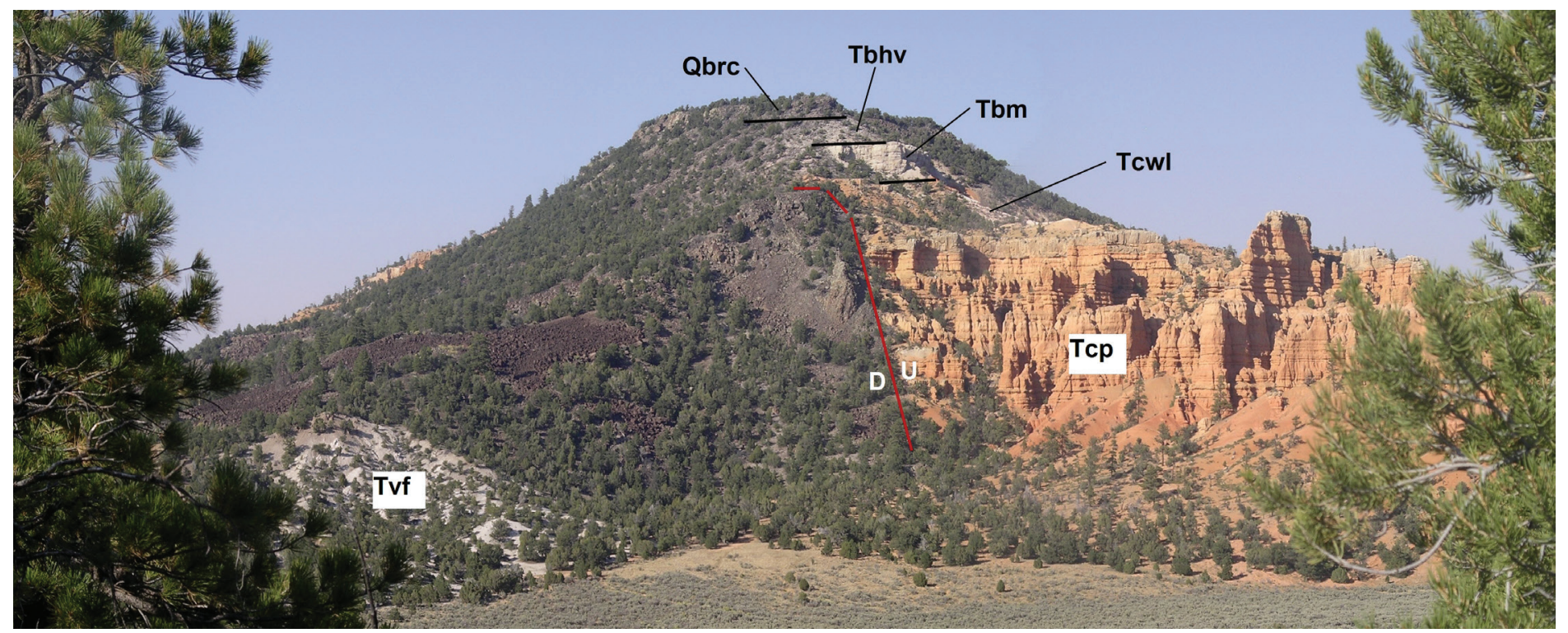

Figure 1. View north-northeast across Utah Highway 12 to the Sevier fault and Black Mountain at the entrance to Red Canyon. The 500,000-year-old Red Canyon lava flow (Qbrc) on the north side of the canyon erupted from vents on the down-dropped side of the Sevier fault (red line, $D=$ down, $U=u p$ ) and flowed eastward across the fault, which then did not form a significant topographic barrier as it does today (at the time the lava flow erupted, the fault juxtaposed tilted, non-resistant late Tertiary basin-fill deposits in the hanging wall against non-resistant, basal Brian Head strata in the footwall). The lava flow has since been displaced about 650 feet (200 m), yielding a vertical slip rate of $0.4 \mathrm{~mm} / \mathrm{yr}$ (Lund and others, 2008). The trace of the fault is largely concealed by talus and landslides. Tvf, late Tertiary basin-fill deposits; Tbhv, basal Brian Head strata; Tbm, conglomerate at Boat Mesa; Tcwl, lower unit of the white member of the Claron Formation; Tcp, pink member of the Claron Formation.

\section{INTRODUCTION}

The Sevier fault is spectacularly displayed on the north side of Utah Highway 12 at the entrance to Red Canyon, where it offsets a 500,000-year-old basaltic lava flow. The fault is one of several active, major faults that break apart the western margin of the Colorado Plateau in southwestern Utah. The Sevier fault is a "normal" fault, a type of fault that forms during extension of the earth's crust, where one side of the fault moves down relative to the other side. In this case, the down-dropped side (the hanging wall) is west of the fault; the upthrown side (the footwall) lies to the east. The contrasting colors of rocks across the fault make the fault stand out in vivid detail (figure 1).

Immediately south of Red Canyon, the 5-million-year-old Rock Canyon lava flow, which erupted on the eastern slope of the Markagunt Plateau, flowed eastward and crossed the fault (which at the time juxtaposed non-resistant fan alluvium against coarse-grained volcaniclastic deposits) (figure 2) (Biek and others, 2015). The flow is now offset 775 to 1130 feet $(235-345 \mathrm{~m})$ along the main strand of the fault, yielding an anomalously low vertical slip rate of about $0.05 \mathrm{~mm} / \mathrm{yr}$ (Lund and others, 2008). However, this eastern branch of the Sevier fault accounts for only part of the total displacement on the fault zone. A concealed, down-to-the-west fault is present west of coarse-grained volcaniclastic strata at the base of the Claron cliffs. Seismic reflection data indicate that the total displacement on the fault zone in this area is about 3000 feet (900 m) (Lundin, 1987, 1989; Davis, 1999).

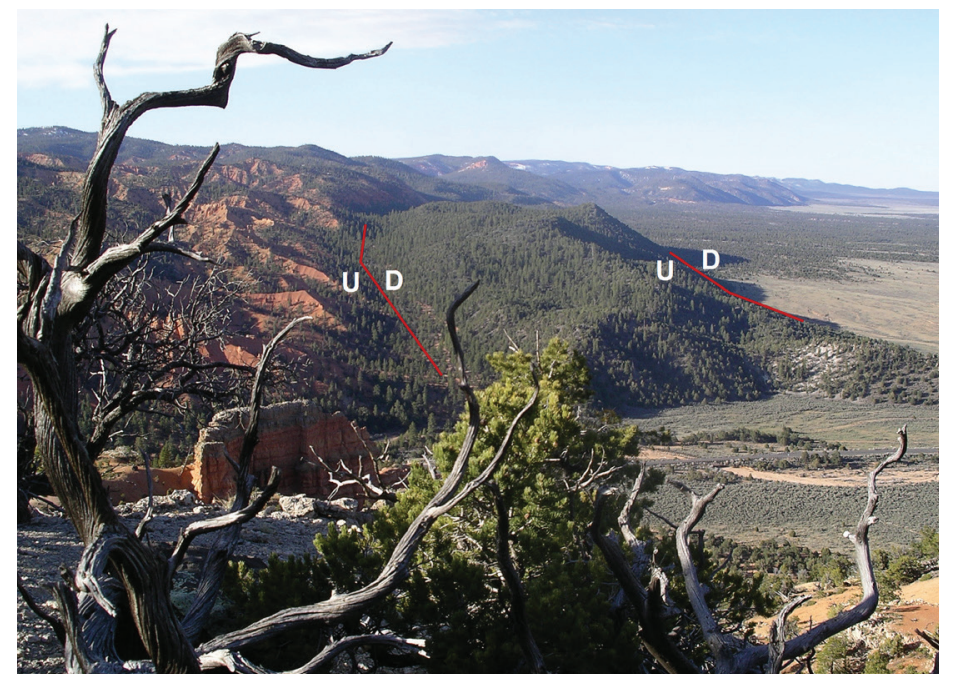

Figure 2. View south along the Sevier fault zone just south of Red Canyon. Pinyon-juniper-covered hill between the two fault strands $(U=$ upthrown side, $D=$ down-dropped side) is mostly coarse-grained volcaniclastic strata, locally capped by the 5-million-year-old Rock Canyon lava flow, a remnant of which is preserved just out of view to left in this photo. Wilson Peak is at upper left.

\section{LOCATION}

Park at the scenic overlook and rest stop 2.6 miles $(4.2 \mathrm{~km})$ east of the junction of Utah Highway 12 and U.S. Highway 89. Coordinates are $37^{\circ} 44^{\prime} 38^{\prime \prime}, 112^{\circ} 19^{\prime} 46^{\prime \prime}$. Picnic tables and pit toilets are available. Figures 3 and 4 show a geologic map and cross section of this area. Several scenic pullouts and a paved bicycle trail make Red Canyon a popular spot for visitors on their way to nearby Bryce Canyon National Park. A U.S. Forest Service visitor center with restroom facilities is about one mile $(1.6 \mathrm{~km})$ east up Red Canyon. 


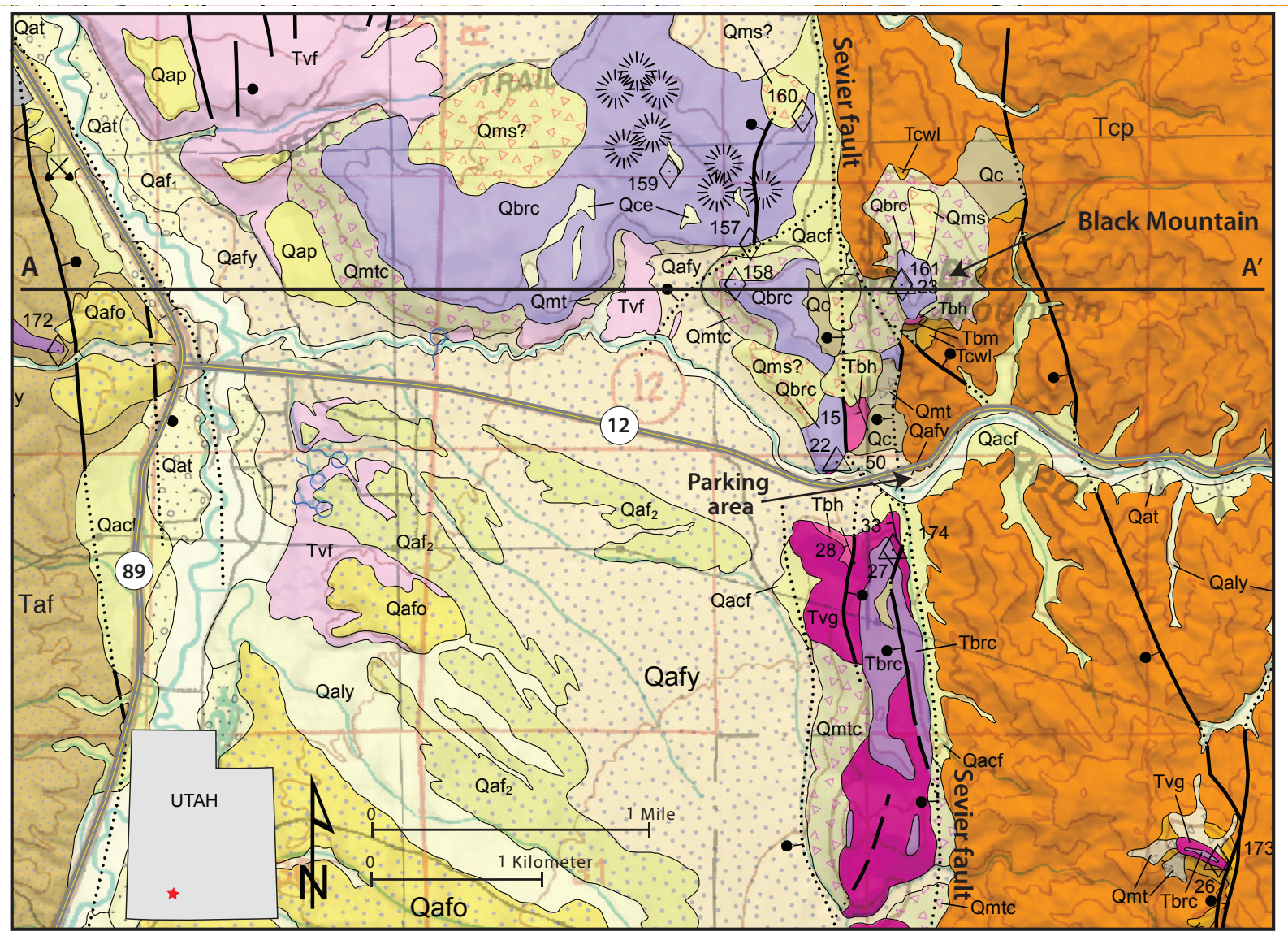

Figure 3. Geologic map of the Red Canyon area, showing parking area to view the Sevier fault zone. Note numerous vent areas (stars) on Rock Canyon lava flow. $Q=$ various surficial deposits; $Q b r c=$ Red Canyon lava flow; Tbrc = Rock Canyon lava flow; Taf = old alluvial-fan deposits; Tvg = coarse-grained volcaniclastic deposits; Tvf = fine-grained volcanic deposits; Tbh = Brian Head Formation; Tcp = pink member of the Claron Formation. Modified from Biek and others (2015).

West

East

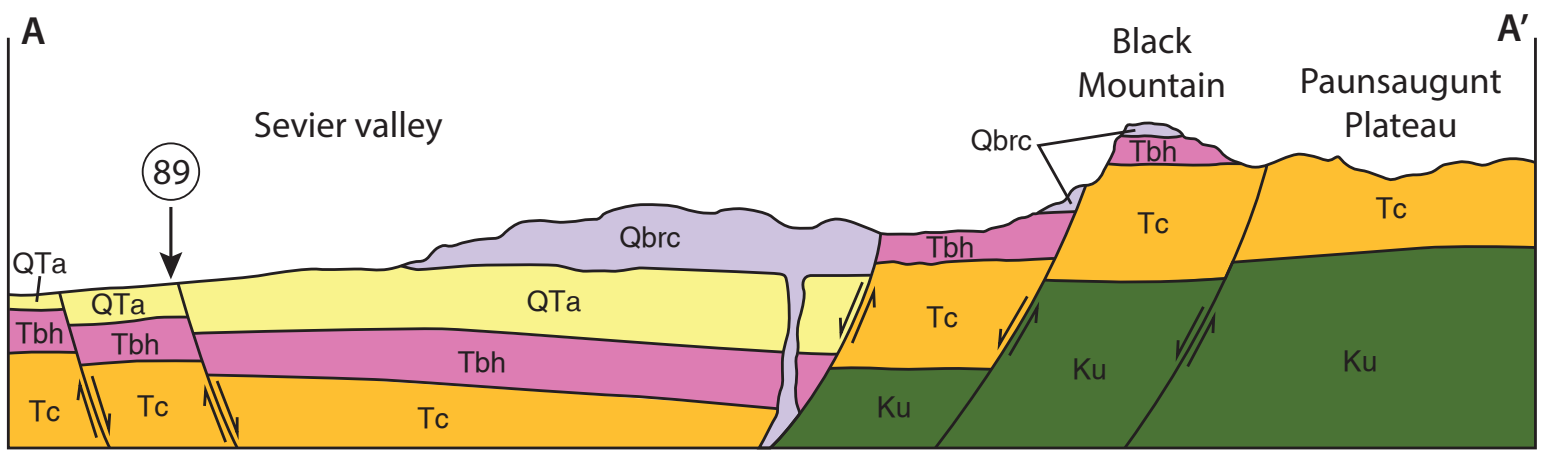

Figure 4. Schematic cross section showing displacement across the Sevier fault near Red Canyon. Basin-fill sediments (QTa) were stripped off the upthrown side of the fault prior to deposition of the Red Canyon lava flow (Qbrc). See figure 3 for cross section location and rock unit names. 


\section{SEVIER FAULT}

The Sevier fault extends from south of the Grand Canyon northward to the southern part of the Marysvale volcanic field, a distance of at least 150 miles $(250 \mathrm{~km})$; it is known as the Toroweap fault in Arizona (figure 5) (Lund and others, 2008). The fault lies at the western base of the southern Sevier Plateau and Paunsaugunt Plateau. Northward, fault-bounded basins in the heart of the Marysvale volcanic field, including the Circleville, Marysvale, and Monroe areas, are on structural trend with the Sevier fault zone, indicating that the fault bisects the volcanic field and links up with down-to-the-west normal faults in southern Sevier Valley south of Richfield (Hintze and others, 2003; Rowley and others, 2005).

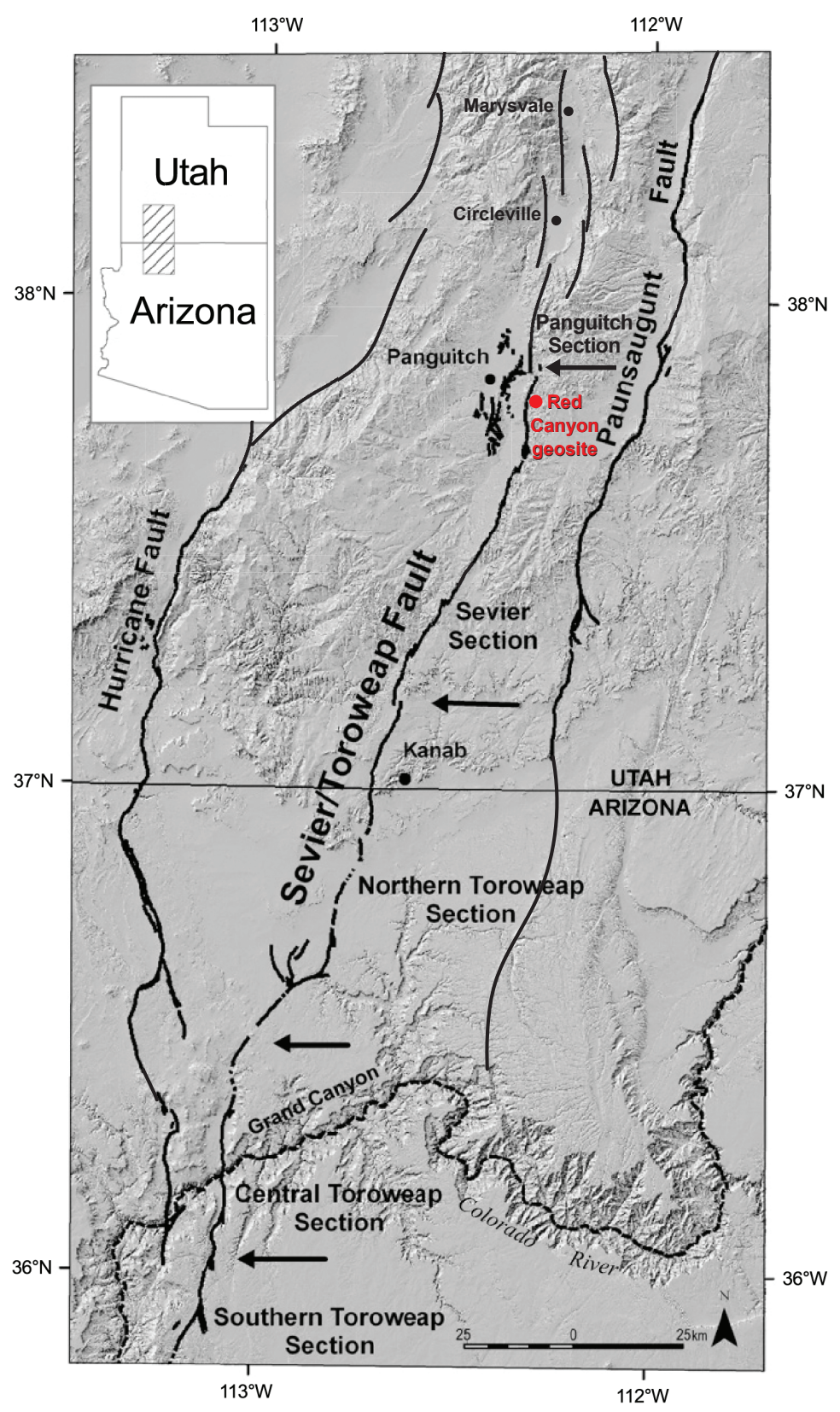

Figure 5. The Sevier-Toroweap, Hurricane, and Paunsaugunt faults in the Basin and Range-Colorado Plateau transition zone. Arrows indicate fault section boundaries. Each section likely has a different rupture history and rate of longterm slip. Modified from Lund and others (2008).
Like most long normal faults, the Sevier fault is composed of discrete parts that tend to rupture independently (Lund and others, 2008). Although Lund and others (2008) suggested that Hillsdale Canyon, about 3 miles $(5 \mathrm{~km}$ ) south of Red Canyon, may mark a segment boundary on the fault zone, Biek and others (2015) suggested a different boundary farther north, east of Panguitch. There, a complexly faulted bedrock high and associated graben in the hanging wall separate the Hatch part of the valley on the south from the Panguitch part of the valley on the north. In this area, numerous scarps are present on old alluvial fans where they collectively form a northeast-trending graben. This area also corresponds to the south end of the Sevier Plateau, which is of higher elevation and relief than the Paunsaugunt Plateau. This northern, "Panguitch" section of the fault zone appears to terminate several miles north of the junction of Utah Highway 20 and U.S. Highway 89, where it devolves into an anastomosing series of down-to-the-west and down-to-theeast normal faults before linking up with the eastern bounding fault of Circleville Valley (figure 5) (Rowley and others, 2005).

Displacement on the Sevier fault generally increases south to north along its length; it is about 3000 feet $(900 \mathrm{~m})$ at Red Canyon (Lundin, 1987, 1989; Davis, 1999; Lund and others, 2008). Apart from scarps in the hanging wall near Panguitch, no scarps on unconsolidated surficial deposits are present along the main trace of the Sevier fault in Utah. The inception of faulting on the Sevier fault zone is poorly known but widely cited as middle Miocene, 12 to 15 million years ago (see, for example, Davis, 1999).

\section{CLARON FORMATION}

Many people get their first glimpse of the spectacularly colored, hoodoo-forming Claron Formation not at Bryce Canyon National Park or Cedar Breaks National Monument, but here in Red Canyon. Wide pullouts along the road attest to the area's popularity, a stark contrast from the sage-covered, high-elevation basin and tree-covered plateau to the west. Apart from the bright pink, orange, and red rocks themselves (figure 6), what attracts most people are the fantastic variety of fins, spires, and hoodoos that the Claron Formation naturally erodes into.

Hoodoos form by relatively rapid erosion of alternating resistant and less-resistant beds in combination with pervasive jointing, high precipitation rates, and some 200 freeze-thaw cycles per year. Freeze-thaw cycles loosen rock, whereas summer thunderstorms work to wash it away. Importantly however, new research shows that the local stress field is a key factor that gives rise to the hoodoos; erosional processes act within that stress field to create these fantastic forms (Bruthans and others, 2014). The vertical stress imparted by the weight of a resistant caprock holds grains together; as erosion removes some grains, the stress between the remaining grains increases, holding them more tightly together 


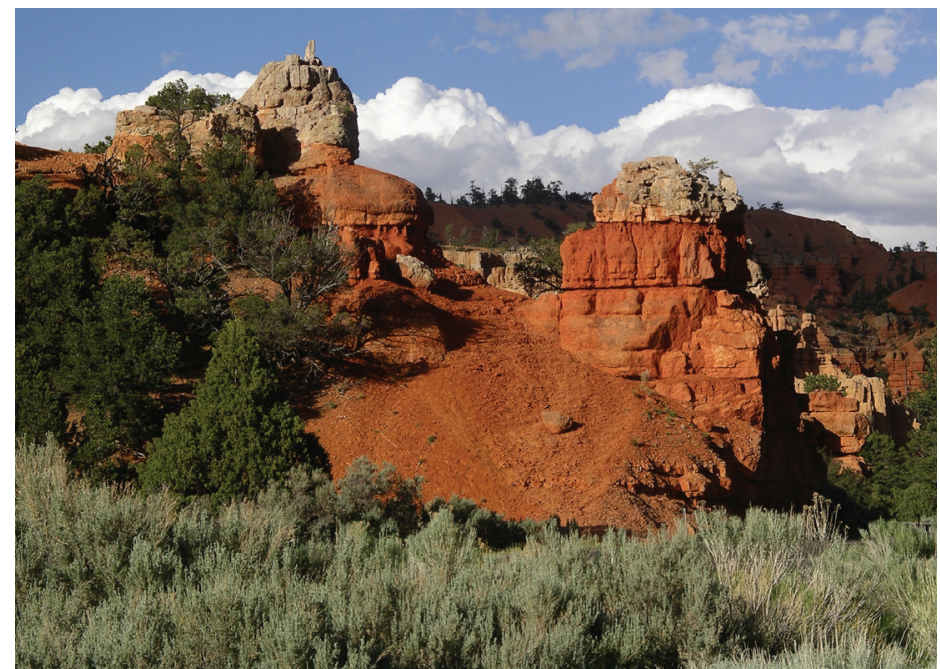

Figure 6. Brightly colored Claron Formation at the entrance to Red Canyon. Yellowish-brown caprocks are pebbly conglomerate, evidence that these sedimentary rocks were deposited in stream and floodplain settings.

and making it harder to erode the sides of the hoodoos. Erosion is thus slowed and the hoodoos tend to grow taller over time as intervening slopes erode. In addition, in the dry climate of southern Utah, much of the precipitation that falls on the hoodoos quickly evaporates, leaving behind any cement that the water started to dissolve and thus making the rind of the hoodoos more resistant.

\section{ACKNOWLEDGMENTS}

My knowledge of southwestern Utah geology comes from years of geologic mapping supported largely by the Utah Geological Survey and U.S. Geological Survey. As the acknowledgments of those many published geologic maps attest, I am indebted to a great many people for their help over the years. Thanks to Grant Willis and Mike Hylland (UGS) and Kimm Harty (UGS retired) for their insightful reviews and to Jon Good (UGS) for drafting the figures.

\section{REFERENCES}

Biek, R.F., Rowley, P.D., Anderson, J.J., Maldonado, F., Moore, D.W., Hacker, D.B., Eaton, J.G., Hereford, R., Filkorn, H.F., and Matyjasik, B., 2015, Geologic map of the Panguitch 30' x 60' quadrangle, Garfield, Iron, and Kane Counties, Utah: Utah Geological Survey Map 270DM, 162 p., 3 plates, scale $1: 62,500$.

Bruthans, J., Soukup, J., Vaculikova, J., Filippi, M., Schweigstillova, J., Mayo, A.L., Masin, D., Kletetschka, G., and Rihosek, J., 2014, Sandstone landforms shaped by negative feedback between stress and erosion: Nature Geoscience, v. 7, p. 597-601, published online, 20 July 2014 | DOI: 10.1038/NGEO2209.
Davis, G.H., 1999, Structural geology of the Colorado Plateau region of southern Utah, with special emphasis on deformation bands: Geological Society of America Special Paper 342, $157 \mathrm{p}$.

Hintze, L.F., Davis, F.D., Rowley, P.D., Cunningham, C.G., Steven, T.A., and Willis, G.C., 2003, Geologic map of the Richfield 30' x 60' quadrangle, southeast Millard County and parts of Beaver, Piute, and Sevier Counties, Utah: Utah Geological Survey Map 195, 2 plates, scale 1:62,500.

Lund, W.R., Knudsen, T.R., and Vice, G.S., 2008, Paleoseismic reconnaissance of the Sevier fault, Kane and Garfield Counties, Utah: Utah Geological Survey Special Study 122, Paleoseismology of Utah, volume 16, $31 \mathrm{p}$.

Lundin, E.R., 1987, Thrusting of the Claron Formation, the Bryce Canyon region, Utah: Tucson, University of Arizona, M.S. thesis, $51 \mathrm{p}$.

Lundin, E.R., 1989, Thrusting of the Claron Formation, the Bryce Canyon region, Utah: Geological Society of America Bulletin, v. 101, p. 1038-1050.

Rowley, P.D., Vice, G.S., McDonald, R.E., Anderson, J.J., Machette, M.N., Maxwell, D.J., Ekren, E.B., Cunningham, C.G., Steven, T.A., and Wardlaw, B.R., 2005, Interim geologic map of the Beaver 30' x 60' quadrangle, Beaver, Piute, Iron, and Garfield Counties, Utah: Utah Geological Survey Open-File Report 454, 27 p., 1 plate, scale 1:100,000. 